\title{
MODERATE HEAT TREATMENTS ENHANCE THE QUALITY OF TRADED NATURAL SHEA BUTTER
}

\author{
$*^{1}$ Oyedele, A. O., ${ }^{1}$ Igbeneghu, O. A., ${ }^{1}$ Alade, T. I., and ${ }^{2}$ Akinmusire, O. O. \\ ${ }^{1}$ Department of Pharmaceutics, Faculty of Pharmacy, Obafemi Awolowo University, Ile-Ife Nigeria. \\ ${ }^{2}$ Department of Microbiology, Faculty of Science, University of Maiduguri, Maiduguri Nigeria. \\ *Corresponding author's email address: aoyedele@oauife.edu.ng, Tel. 08033703029
}

(Received: 20 $0^{\text {th }}$ October, 2019; Accepted: $2^{\text {nd }}$ January, 2020)

\section{ABSTRACT}

\begin{abstract}
Natural shea butter (NSB), extracted by traditional methods resulting in its poor quality, is nevertheless widely traded within Africa and beyond due to its several useful applications. This study examined effects of simulated laboratory/domestic heat treatments on quality of the commodity obtained from a cross section of Nigerian markets. Physicochemical and microbiological qualities of NSB samples procured from four selected markets located across three Nigerian states were evaluated by standard methods before and after graduated thermal stress treatments from 50 through $120^{\circ} \mathrm{C}$ over 5,15 , or 30 min durations, respectively, and filtration at $60{ }^{\circ} \mathrm{C}$. Mean physicochemical quality values of NSB samples determined, namely: specific gravity at $29^{\circ} \mathrm{C}(0.90-0.94)$; softening, melting temperatures $\left(33-36,36-39^{\circ} \mathrm{C}\right.$; respectively); acid, iodine, and saponification values $(10.5-$ 29.3, 46.4-59.1, 110-470; respectively), were not adversely or significantly altered by the thermal treatment types and stresses. Whereas all untreated NSB samples demonstrated microbial contamination (total viable counts: $10^{3}-10^{6} \mathrm{cfu} / \mathrm{g}$ ) with Pseudomonas, Klebsiella, Staphylococcus, Bacillus, Aspergillus, or Candida species, the graduated heat treatments produced varied sanitizing effects. Higher temperatures $\left(100,120{ }^{\circ} \mathrm{C}\right)$ gave greater and more rapid cleansing action than the lower temperatures $\left(50,75^{\circ} \mathrm{C}\right)$, both intensity-ranges being aided by length of holding time. Hot filtration eliminated all the NSB contaminants. In conclusion, while untreated NSB is found grossly contaminated by microbes, unhygienic and unsafe for human use, this study has demonstrated efficient contaminants-cleansing action of heat treatments $\left(\geq 100^{\circ} \mathrm{C} \times \geq 30 \mathrm{~min}\right)$ on NSB , and the total sanitizing effect of hot filtration process.
\end{abstract}

Key words: Natural shea butter, Physicochemical quality, Microbiological quality, Heat treatment, Hot filtration.

\section{INTRODUCTION}

Shea butter is the natural fat extracted from kernels of the African shea tree, Vitellaria paradoxa Gaertn. widely traded within and beyond Africa due to its several domestic and industrial uses (Djekota et al., 2014). The shea tree is indigenous to African savanna and is found in Mali, Cameroon, Côte d'Ivoire, Ghana, Guinea, Togo, Nigeria, Sudan, Senegal and Ethiopia (Okullo et al., 2004). Extraction process of shea butter in West Africa falls into three main categories: manual traditional, semi-mechanized, and fully mechanized industrial systems. The traditional method predominates but is not standardized and is performed by rural-based women in shea butter processing communities using manual methods to extract about $60 \%$ of the crude (also called "natural") shea butter produced in West Africa (Addaquay, 2004). "Refining" (modifying and cleaning) of the crude butter, which occasionally follows the traditional processing, involves four major stages: degumming and neutralization (to remove constituents unfit for human consumption), followed by bleaching and deodorization that introduce chemicals or catalysts that must be subsequently removed by "re-refining" at end of the process. Yet, the natural (unrefined) shea butter, considered poorer in quality and attracting lower market prices, comprises the most exports of shea butter from West Africa because the traditional processing holds an important market niche for the ever-increasing demand for pristine natural products (Addaquay, 2004).

The general preference for, and importance of natural shea butter over the years has prompted studies into its standardization criteria and evaluation of its qualities. Mohagir et al. (2015) reported on optimization of decolorizing conditions for crude shea butter, noting temperature, adsorbent dose and contact time as 
the most influential factors. Bup et al. (2011) and Megnanou and Niamke (2013) studied the effects of kernel pretreatment, quality and processing on resultant shea butter quality toward optimizing the production process. Also Honfo et al. (2012) studied the sanitary and physicochemical qualities of shea butter sold in Republic of Benin markets and found germs, yeasts and mould contaminating the product depending on the market locations. Honfo et al. (2011) had earlier noted, while examining the effect of storage conditions on shea butter quality, that poor packaging and storage conditions were key constraints for quality assurance and responsible for poor market shea butter qualities. Shea nut cake in Ghana (a byproduct of shea butter refining) was found contaminated with faecal coliform bacteria, Escherichia coli and other microbes (AbdulMumeen, 2013).

The shea tree in Nigeria grows in Kaduna, Kebbi, Kwara, Niger and Oyo states, and shea butter extraction using the indigenous techniques is commonly carried out among the rural dwellers in these states (Warra, 2011). Reports indicate local uses of the natural butter to include: for domestic cooking, treatment of rheumatic pain, minor bone dislocation, nasal congestion and nostril inflammations (Goreja, 2004; Olaniyan and Oje, 2007). Shea butter is also reported to have emollient, moisturizing effect on skin and scalp, able to soften, soothe the skin and accelerate healing after circumcision, and prevent stretch marks on African pregnant women (Goreja, 2004). Adesiji et al. (2015) reported shea butter processing in Kwara state to involve manual harvesting, washing and de-pulping of shea fruits; cracking, roasting and milling of selected kernels, and manual kneading, mixing, filtration and packaging of the resulting extracted fat; while Ademola et al. (2012) noted that shea butter processing at Atisbo, Oyo state involved slow and tedious, manual processes that could turn out products of questionable, uncertain quality.

In view of several uses of commercial natural shea butter: domestic (food, confectionery), cosmetic (topical skin care), folklore therapeutic and industrial uses, the present study was aimed at determining the effects of thermal treatments on its physicochemical and microbiological parameters.

\section{MATERIALS AND METHODS Sample Collection}

Samples of shea butter (approx. $300 \mathrm{~g}$ each) were collected in the main urban markets of Ajasse-Ipo ('AJA', Kwara state), Ile-Ife ('IFE', Osun state), Iseyin ('SEY') and Shaki ('SHK', Oyo state, Nigeria), wrapped in aluminum foil and placed in polyethylene bags, and numbered according to their market origins. They were stored in iceboxes containing ice cubes and transported to the laboratory, where they were kept at $4{ }^{\circ} \mathrm{C}$ until tested for physicochemical and microbiological qualities, thermal treatments and re-testing, as later described.

\section{Physicochemical Studies}

The following physicochemical properties of untreated natural shea butter samples (i.e. as procured from different markets), as well as heat treated dry samples (DS, described later) were studied: specific gravity at ambient temperature $\left(29 \pm 2^{\circ} \mathrm{C}\right.$ ), acid value, iodine value, and saponification value determined according to the British Pharmacopoeia (BP, 2009) methods. Softening and melting temperatures of the samples were also determined using the method described by Adebayo and Akala (2005). The temperature at which the sample began to liquefy was defined as the softening point, while the temperature of complete liquefaction was the melting point. The evaluation of heat treated samples was carried out after seven days' shelfstorage, to give sufficient time for their restoration to the stable state (Oyedele, 2016). The data were presented as mean \pm standard error of mean (SEM) of four determinations.

\section{Heat Treatment Conditions and Schedules}

Heat treatments corresponding to those usually meted on vegetable oil or fat ingredients (including shea butter) under domestic, cosmetic or pharmaceutical laboratory production processes $\left(50-120^{\circ} \mathrm{C}\right)$, were used. Each of four selected temperature treatments: 50, 75, 100, and $120{ }^{\circ} \mathrm{C}$ (within $\pm 2{ }^{\circ} \mathrm{C}$ precision) was administered to duplicate $20 \mathrm{~g}$ shea butter samples from each market source, over three predetermined time 
durations of 5,15 , or 30 min, respectively; and under two separate, simulated in-use conditions namely: in presence of water (to model a hydrated sample, ' $H S^{\prime}$ ), or in absence of water (a dry sample ' $\left.D S^{\prime}\right)$. The HS was produced by aseptic incorporation of sterile water $(16.7 \% \mathrm{w} / \mathrm{w})$, while the DS comprised the sample studied as collected from source.

Heat treatment procedure: Each sample (HS or DS) was weighed into platinum dish and heated on hot plate to attain the desired temperature and duration, monitored with a thermometer and timer, then the heat source was removed. The oil (melted fat) remaining after the treatment $(\approx 15$ $\mathrm{ml}$ aliquots) was allowed to cool to $\approx 50{ }^{\circ} \mathrm{C}$, and was then placed in pre-labeled, sterile glass receptacles and stored at $4{ }^{\circ} \mathrm{C}$ for subsequent analyses.

\section{Hot filtration}

Additional $20 \mathrm{~g}$ DS shea butter sample from each market source was weighed (aseptically) into presterilized glass beakers, heated to melt and filtered through Whatman No. 1 filter paper in a hot-air oven maintained at $60 \pm 2{ }^{\circ} \mathrm{C}$ (in $\geqslant 60 \mathrm{~min}$ filtration process). The filtrate was allowed to cool $\left(\approx 50{ }^{\circ} \mathrm{C}\right)$ and then evaluated for its physicochemical and microbiological qualities.

\section{Microbiological Studies Total viable count}

Total microbial counts of the crude, heat-treated and hot-filtered samples were determined: $1 \mathrm{~g}$ samples were dispersed aseptically in $10 \mathrm{ml}$ aliquots of sterile (pre-autoclaved) aqueous Tween 80 solution, then diluted serially with sterile water $\left(10^{1}-10^{4}\right)$ and plated in recovery media, as follows- $0.5 \mathrm{ml}$ aliquots of the respective dilutions were mixed in sterile $15 \mathrm{ml}$ melted and cooled growth medium, namely: nutrient agar (NA; Oxoid) and Sabouraud dextrose agar (SDA; Oxoid), for recovery of bacterial and fungal cells, respectively, and then incubated at $37^{\circ} \mathrm{C}$ for $24-48$ $\mathrm{h}$ (for bacteria) or at $25{ }^{\circ} \mathrm{C}$ for $24-72 \mathrm{~h}$ (for yeast/fungi). Following the incubation, the numbers of colonies growing on the plates were counted to determine total viable count estimates of microbes in the original samples.

\section{Cultural, morphological and biochemical characterization}

Fresh NA and SDA plates were streaked with the shea butter samples from different markets for growth of isolated colonies, and incubated at 37 ${ }^{\circ} \mathrm{C}$ for $24 \mathrm{~h}$ (bacteria) and $25^{\circ} \mathrm{C}$ for $48 \mathrm{~h}$ (fungi). Distinct colonies from the plates were then subcultured onto fresh identical plates to obtain pure cultures. The pure isolates were again sub-cultured onto identical agar plates for maintenance of the organisms. Pure single isolates were identified as those colonies showing the same morphological characteristics. The maintenance plates for the isolates on NA or SDA were appropriately labeled and stored in refrigerator at $4{ }^{\circ} \mathrm{C}$.

Mould growths on SDA plates were identified by their macroscopic (visible features on the growth media) and microscopic characteristics under the microscope using lacto phenol cotton blue slide mounts (Samson and van Reenan-Hoekstra, 1988). Besides general classification by morphological characteristics, all the isolated pure bacterial cultures were further identified by their staining reactions (using Gram's staining technique) to distinguish between Gram-positive and Gram-negative bacteria, and biochemical tests described by Murray et al. (1995) and Couwan and Steel (1985). Isolates growing on the maintenance plates were sub-cultured into diagnostic agar plates namely: Eosine methylene blue, mannitol salt, and Mac Conkey agar plates, and incubated at $37^{\circ} \mathrm{C}$ for $24 \mathrm{~h}$ to test for growth, and production of acid, in order to ascertain identity of coliforms and differentiate lactose fermenters from nonlactose fermenters.

\section{Data Analysis}

Data obtained were evaluated by two-way analysis of variance (ANOVA) followed by the F-test, and Student's $t$-test for paired mean comparisons, to determine statistical significance of differences in computed mean values. In all cases, differences were considered significant at the $\mathrm{p} \leqslant 0.05$ level.

\section{RESULTS \\ Physicochemical Properties of Natural Shea Butter with and without Heat Treatments}

The results of physicochemical evaluation of natural shea butter from different Nigerian 
markets are as stated in table 1 . The table shows data for the untreated (ambient temperature) samples, hot $\left(60{ }^{\circ} \mathrm{C}\right)$ filtered samples, and those subjected to the highest temperature-treatment test level $\left(120^{\circ} \mathrm{C}\right)$. The specific gravity, softening and melting point values determined for the untreated samples were very similar to those for heat-treated samples (Table 1). Each of these physical properties of natural shea butter exhibited no significant difference in their mean values $(p>0.05)$ within and across the different market sources.

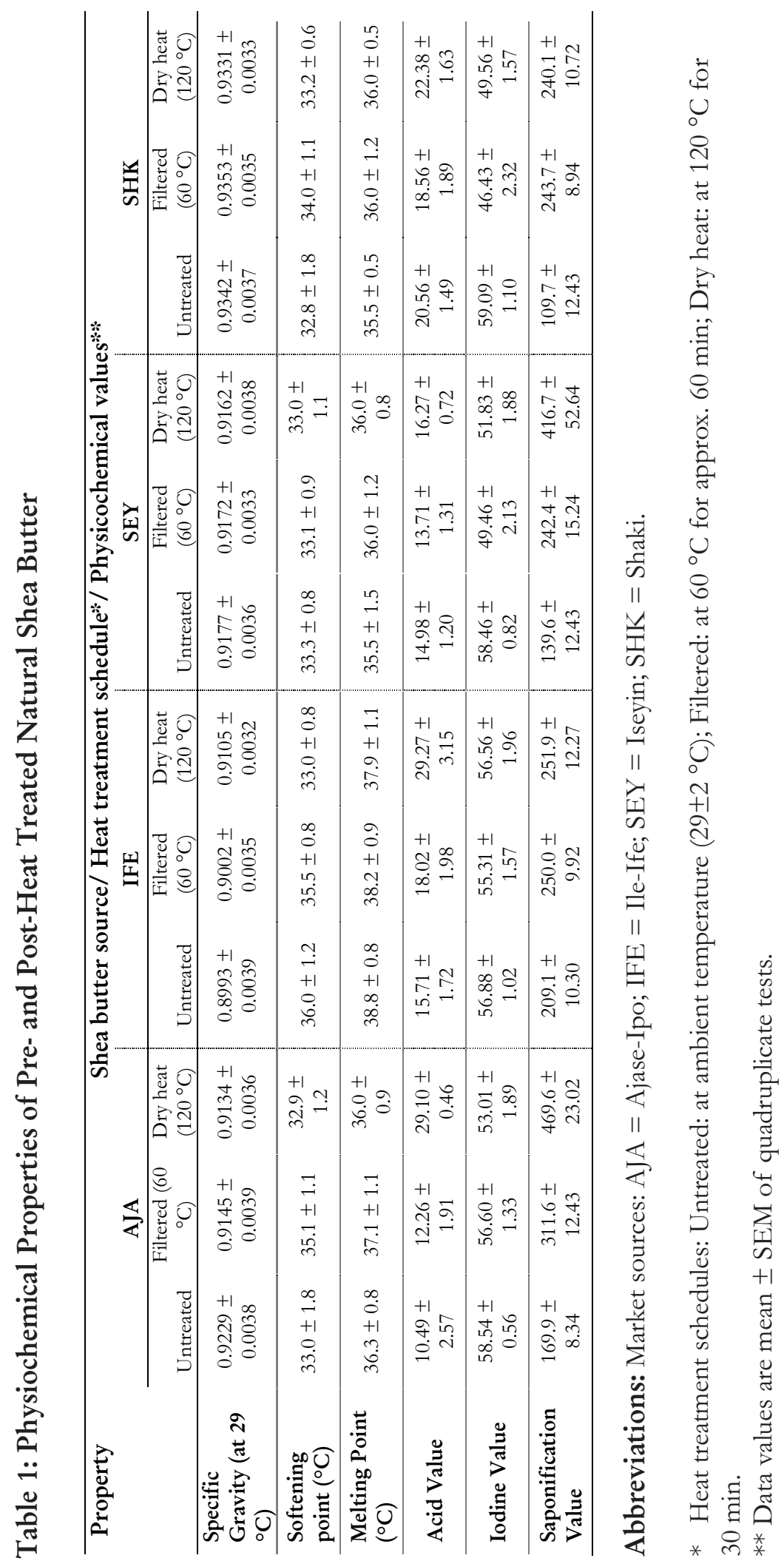


On the other hand, a gradual, minimal increase in the average acid and saponification values were noticed; while a gradual, minimal decrease in the mean iodine values were generally found to occur (in most cases) with increase in the treatment temperatures, when those properties for the untreated natural shea butter (room-temperature) samples were compared against those for the heattreated $\left(60,120{ }^{\circ} \mathrm{C}\right.$ temperature) samples from each market (Table 1). However, the differences in those mean values for each of those parameters were found to be not significant $(p>0.10)$ by the $F$ test variance estimates comparison across the four similar market sources.

\section{Microbiological Quality Status of Natural Shea Butter Samples}

All the shea butter samples demonstrated viable microbial contamination loads of $10^{3}-10^{6}$ colony forming units per gram (cfu/g) (Table 2). The contaminating organisms detected in the samples included bacteria: Pseudomonas, Klebsiella, Staphylococcus and Bacillus species; and fungal forms: Candida and Aspergillus species (Table 3).

Table 2: Microbial Loads of Natural Shea Butter Samples from Nigerian Markets

\begin{tabular}{lcccc}
\hline & \multicolumn{4}{l}{ Source of Shea Butter sample/ Microbial load estimate (cfu/g) } \\
\cline { 2 - 5 } $\begin{array}{l}\text { Microbe } \\
\text { Type }\end{array}$ & AJA & IFE & SEY & SHK \\
\hline Bacteria & $5.40 \times 10^{\wedge} 6$ & $3.76 \times 10^{\wedge} 4$ & $4.20 \times 10^{\wedge} 6$ & $4.64 \times 10^{\wedge} 3$ \\
Fungi & $2.30 \times 10^{\wedge} 6$ & $2.20 \times 10^{\wedge} 4$ & $2.70 \times 10^{\wedge} 6$ & $2.00 \times 10^{\wedge} 4$ \\
\hline
\end{tabular}

Abbreviations: Sample source: AJA = Ajasse-Ipo; IFE = Ile-Ife; SEY = Iseyin; SHK $=$ Shaki.

Table 3: Identities of Isolates from Natural Shea Butter from some Nigerian Markets

\begin{tabular}{|c|c|c|c|c|c|}
\hline \multicolumn{2}{|c|}{ BACTERIA } & \multicolumn{2}{|c|}{$\underline{\text { YEAST }}$} & \multicolumn{2}{|c|}{$\underline{\text { MOULD }}$} \\
\hline $\begin{array}{l}\text { Sample Source/ } \\
\text { Isolate's ID } \\
\text { Number }\end{array}$ & Identity of Isolate & $\begin{array}{l}\text { Sample Source/ } \\
\text { Isolate's ID } \\
\text { Number }\end{array}$ & Identity of Isolate & $\begin{array}{l}\text { Sample Source/ } \\
\text { Isolate's ID } \\
\text { Number } \\
\end{array}$ & Identity of Isolate \\
\hline AJA 1 & Staph spp & AJA 4 & Candida spp & AJA 8 & Aspergillus spp \\
\hline AJA 2 & Klebsiella spp & AJA 5 & Candida spp & AJA 9 & Aspergillus spp \\
\hline AJA 3 & Bacillus spp & AJA 6 & Candida spp & IFE 7 & Aspergillus spp \\
\hline IFE 1 & $\begin{array}{l}\text { Pseudomonas } \\
\text { aeruginosa }\end{array}$ & AJA 7 & Candida spp & SEY 3 & Aspergillus spp \\
\hline IFE 2 & Pseudomonas spp. & IFE 6 & Candida spp & SHK 3 & Aspergillus spp \\
\hline IFE 3 & Bacillus spp. & SEY 2 & Candida spp & & \\
\hline IFE 4 & Bacillus polymyxa & SHK 2 & Candida spp & & \\
\hline IFE 5 & Bacillus alvei & & & & \\
\hline SEY 1 & Staph spp & & & & \\
\hline SHK 1 & Staph spp & & & & \\
\hline
\end{tabular}

Abbreviations: Sample source: AJA = Ajasse-Ipo; IFE = Ile-Ife; SEY = Iseyin; SHK = Shaki.

Effects of Heat Treatments on the Microbiological Quality of Shea Butter

The graduated thermal treatments meted on the shea butter samples produced varied sanitizing effects on the microbiological qualities of the moist and dry samples. No viable microbial contaminants were recovered in all the samples exposed to $120{ }^{\circ} \mathrm{C}$ temperature for the least (5 
min) treatment duration; and all the samples from two (SEY and SHK) of the four market sources also revealed complete sanitization of (total kill in) the samples exposed to $100^{\circ} \mathrm{C}$ temperature (Table 4). Similarly, no microbes were recovered from all the samples that underwent hot filtration. On the other hand, the least temperature treatment on the samples $\left(50{ }^{\circ} \mathrm{C}\right)$ only reduced the microbial loads (from $10^{6}$ to $10^{3}$ or less) and, in most cases, did not produce total kill over $30 \mathrm{~min}$ (Table 4).

\section{Table 4: Residual Microbial Contamination following Thermal Treatments on Natural Shea Butter from some Nigerian Markets}

\begin{tabular}{|c|c|c|c|c|c|c|c|c|c|}
\hline \multirow[b]{3}{*}{$\begin{array}{l}\text { Sample } \\
\text { Source }\end{array}$} & \multirow{3}{*}{$\begin{array}{c}\text { Treatment } \\
\text { Condition of } \\
\text { Sample } \\
\text { (HS/DS) }\end{array}$} & \multirow{3}{*}{$\begin{array}{c}\text { Treatment } \\
\text { Process or } \\
\text { Temperature } \\
\left({ }^{\circ} \mathrm{C}\right)\end{array}$} & \multicolumn{7}{|c|}{ Treatment Duration (min.)/ Microbe Type/ Viable Counts (cfu/gram) } \\
\hline & & & \multicolumn{2}{|c|}{5} & \multicolumn{2}{|c|}{15} & \multicolumn{2}{|c|}{30} & \multirow{2}{*}{$\begin{array}{c}60 \\
\text { Bacteria/ } \\
\text { Fungi }\end{array}$} \\
\hline & & & Bacteria & Fungi & Bacteria & Fungi & Bacteria & Fungi & \\
\hline \multirow[t]{4}{*}{ AJA } & $\begin{array}{l}\text { Hydrated } \\
\text { sample }\end{array}$ & 50 & $7.60 \times 10^{\wedge} 5$ & $1.27 \times 10^{\wedge} 5$ & $2.87 \times 10^{\wedge} 5$ & $5.94 \times 10^{\wedge} 4$ & $2.65 \times 10^{\wedge} 5$ & $7.01 \times 10^{\wedge} 3$ & \\
\hline & & 75 & $1.04 \times 10^{\wedge} 5$ & $4.01 \times 10^{\wedge} 3$ & $6.67 \times 10^{\wedge} 4$ & $5.00 \times 10^{\wedge} 3$ & $4.44 \times 10^{\wedge} 4$ & $3.00 \times 10^{\wedge} 2$ & \\
\hline & & 100 & $4.00 \times 10^{\wedge} 4$ & $9.00 \times 10^{\wedge} 2$ & $1.20 \times 10^{\wedge} 2$ & $3.60 \times 10^{\wedge} 2$ & $1.00 \times 10^{\wedge} 2$ & 0 & \\
\hline & & 120 & 0 & 0 & 0 & 0 & 0 & 0 & \\
\hline \multirow[t]{5}{*}{ AJA } & Dry sample & 50 & $2.24 \times 10^{\wedge} 5$ & $9.20 \times 10^{\wedge} 4$ & $1.12 \times 10^{\wedge} 4$ & $6.00 \times 10^{\wedge} 3$ & $2.20 \times 10^{\wedge} 4$ & $1.00 \times 10^{\wedge} 3$ & \\
\hline & & 75 & $3.24 \times 10^{\wedge} 4$ & $1.00 \times 10^{\wedge} 3$ & $1.40 \times 10^{\wedge} 2$ & $1.00 \times 10^{\wedge} 3$ & 0 & 0 & \\
\hline & & 100 & 0 & 0 & 0 & 0 & 0 & 0 & \\
\hline & & 120 & 0 & 0 & 0 & 0 & 0 & 0 & \\
\hline & & $\begin{array}{c}\text { Hot } \\
\text { filtration }\end{array}$ & & & & & & & 0 \\
\hline \multirow[t]{4}{*}{ IFE } & $\begin{array}{l}\text { Hydrated } \\
\text { sample }\end{array}$ & 50 & $2.56 \times 10^{\wedge} 4$ & $2.15 \times 10^{\wedge} 4$ & $3.11 \times 10^{\wedge} 4$ & $2.71 \times 10^{\wedge} 3$ & $1.10 \times 10^{\wedge} 3$ & $2.40 \times 10^{\wedge} 1$ & \\
\hline & & 75 & $1.00 \times 10^{\wedge} 4$ & $5.01 \times 10^{\wedge} 2$ & $2.51 \times 10^{\wedge} 3$ & $4.12 \times 10^{\wedge} 1$ & $2.00 \times 10^{\wedge} 2$ & 0 & \\
\hline & & 100 & $3.16 \times 10^{\wedge} 2$ & $3.31 \times 10^{\wedge} 1$ & $4.00 \times 10^{\wedge} 1$ & $2.01 \times 10^{\wedge} 1$ & 0 & 0 & \\
\hline & & 120 & 0 & 0 & 0 & 0 & 0 & 0 & \\
\hline \multirow[t]{5}{*}{ IFE } & Dry sample & 50 & $2.88 \times 10^{\wedge} 3$ & $2.52 \times 10^{\wedge} 3$ & $2.51 \times 10^{\wedge} 2$ & $1.67 \times 10^{\wedge} 1$ & $3.10 \times 10^{\wedge} 1$ & $1.01 \times 10^{\wedge} 1$ & \\
\hline & & 75 & $2.10 \times 10^{\wedge} 2$ & $1.51 \times 10^{\wedge} 2$ & $3.51 \times 10^{\wedge} 1$ & 0 & 0 & 0 & \\
\hline & & 100 & 0 & 0 & 0 & 0 & 0 & 0 & \\
\hline & & 120 & 0 & 0 & 0 & 0 & 0 & 0 & \\
\hline & & $\begin{array}{c}\text { Hot } \\
\text { filtration }\end{array}$ & & & & & & & 0 \\
\hline \multirow[t]{4}{*}{ SEY } & $\begin{array}{l}\text { Hydrated } \\
\text { sample }\end{array}$ & 50 & $8.70 \times 10^{\wedge} 5$ & $3.60 \times 10^{\wedge} 4$ & $3.60 \times 10^{\wedge} 4$ & $4.00 \times 10^{\wedge} 4$ & $2.34 \times 10^{\wedge} 4$ & $2.80 \times 10^{\wedge} 4$ & \\
\hline & & 75 & $3.80 \times 10^{\wedge} 4$ & $3.46 \times 10^{\wedge} 3$ & $2.90 \times 10^{\wedge} 4$ & $1.92 \times 10^{\wedge} 3$ & 0 & 0 & \\
\hline & & 100 & 0 & 0 & 0 & 0 & 0 & 0 & \\
\hline & & 120 & 0 & 0 & 0 & 0 & 0 & 0 & \\
\hline \multirow[t]{5}{*}{ SEY } & Dry sample & 50 & $6.40 \times 10^{\wedge} 4$ & $3.60 \times 10^{\wedge} 5$ & $5.80 \times 10^{\wedge} 4$ & $2.00 \times 10^{\wedge} 4$ & $4.70 \times 10^{\wedge} 4$ & $2.70 \times 10^{\wedge} 3$ & \\
\hline & & 75 & $1.60 \times 10^{\wedge} 3$ & $1.48 \times 10^{\wedge} 3$ & 0 & 0 & 0 & 0 & \\
\hline & & 100 & 0 & 0 & 0 & 0 & 0 & 0 & \\
\hline & & 120 & 0 & 0 & 0 & 0 & 0 & 0 & \\
\hline & & $\begin{array}{c}\text { Hot } \\
\text { filtration }\end{array}$ & & & & & & & 0 \\
\hline \multirow[t]{4}{*}{ SHK } & $\begin{array}{l}\text { Hydrated } \\
\text { sample }\end{array}$ & 50 & $3.66 \times 10^{\wedge} 3$ & $1.70 \times 10^{\wedge} 2$ & $3.07 \times 10^{\wedge} 3$ & 0 & 0 & 0 & \\
\hline & & 75 & $2.26 \times 10^{\wedge} 3$ & 0 & $2.00 \times 10^{\wedge} 2$ & 0 & 0 & 0 & \\
\hline & & 100 & 0 & 0 & 0 & 0 & 0 & 0 & \\
\hline & & 120 & 0 & 0 & 0 & 0 & 0 & 0 & \\
\hline \multirow[t]{5}{*}{ SHK } & Dry sample & 50 & $1.70 \times 10^{\wedge} 3$ & $1.70 \times 10^{\wedge} 2$ & 0 & 0 & 0 & 0 & \\
\hline & & 75 & 0 & 0 & 0 & 0 & 0 & 0 & \\
\hline & & 100 & 0 & 0 & 0 & 0 & 0 & 0 & \\
\hline & & 120 & 0 & 0 & 0 & 0 & 0 & 0 & \\
\hline & & $\begin{array}{c}\text { Hot } \\
\text { filtration }\end{array}$ & & & & & & & 0 \\
\hline
\end{tabular}

Abbreviations: $0=$ no growth of recoverable/viable organisms

Sample source: AJA = Ajasse-Ipo; IFE = Ile-Ife; SEY = Iseyin; SHK = Shaki. 
The bacterial contaminants of the samples generally demonstrated greater resilience against the graded heat treatments than the fungi, in that the latter were more efficiently and rapidly eliminated or reduced over 15 or 30 min under 75 ${ }^{\circ} \mathrm{C}$ or $100{ }^{\circ} \mathrm{C}$ treatments (Table 4). Furthermore, the dry samples (DS) from all different markets were more efficiently disinfected by the heat treatments than their hydrated sample (HS) counterparts. Therefore, complete disinfection (total kill) was achieved for all the DS from AJA and IFE sources that underwent $75^{\circ} \mathrm{C}$ treatment for $30 \mathrm{~min}$, but none of their HS counterparts (from same sources and under same treatment) demonstrated total elimination of their contaminants (Table 4). In summary, the higher temperatures $\left(100\right.$ and $\left.120^{\circ} \mathrm{C}\right)$ gave greater and more rapidly sanitizing action than the lower temperatures $\left(50\right.$ and $75^{\circ} \mathrm{C}$ ); and the length of heating time contributed to efficiency of the thermal sanitizing process. Also, hot $\left(60{ }^{\circ} \mathrm{C}\right)$ filtration proved to be an effective sanitizing operation for natural shea butter.

\section{DISCUSSION}

This study has examined physicochemical and microbiological qualities of natural shea butter obtained from a cross section of Nigerian markets, as well as possible damaging or refining effect of model heat treatment levels on the material. As other fatty vegetable oils, shea butter (fat) or oil is non-volatile. But prolonged intense heating $\left(\approx 300^{\circ} \mathrm{C}\right)$ - beyond treatments studied here - oxidizes (decomposes) the fat to produce acrolein (acraldehyde), a volatile liquid (boiling point: $53{ }^{\circ} \mathrm{C}$ ) that emits a strongly lachrymatory vapour and the odour of scorched fat (Alexander et al., 1992; Nawar, 1984). Heat treatments, on the other hand, also cause microbial decimation, which results in a disinfected and more sanitized product.

The major chemical constituents of shea butter are glycerides of palmitic acid, stearic acid, oleic acid and linoleic acid, present as stearo-dioleins, oleo-distearin, palmito-stearin, trioleins and oleopalmito-stearin (Hilditch and Williams, 1964). The iodine values of natural shea butter determined in this study resulted from the presence of unsaturated fatty acid (oleic, linoleic acid) or glyceride components of the fat which reacted, in the iodometric test, with iodine. The moderate thermal stress range examined in the study $\left(50-120^{\circ} \mathrm{C}\right)$ was unable to adversely alter the iodine values; hence their differences were not significant (Table 1).

Also, the increases of acid and saponification values of heat-treated natural shea butter samples (compared to untreated samples) observed in this study (Table 1) were likely due to some heat-aided hydrolytic process. Rancidity, a relatively slow ageing process of fats on long exposure to air, is also due to hydrolysis of the constituent glycerides with liberation of free fatty acids, making the fat exhibit higher acid reaction and a disagreeable odour. The free fatty acid level of natural shea butter had been earlier adjudged the most variable parameter in a study that assessed what quality characteristics were important (Nahm, 2011).

This study of comparative analysis of the physicochemical properties of natural shea butter from Nigerian markets has shown that while its physical properties (specific gravity, softening and melting point values) were virtually unaffected by the range of temperature-stress treatments studied $\left(50-120^{\circ} \mathrm{C}\right)$, its chemical integrityindicating parameters (namely: acid, iodine and saponification values) were quantifiably altered (Table 1). The alteration was, however, limited and indicated no serious injury to the natural fat; in that those chemical properties yet remained within same overall range of the properties of natural shea butter, following the thermal treatments (Table 1). The physicochemical properties of natural shea butter determined (Table 1) were also in agreement with literature reports for natural commercial shea butter elsewhere in Africa (Honfo et al., 2011; Megnanou and Niamke, 2013).

In this study as in others earlier (Honfo et al., 2011; Honfo et al., 2012), considerable numbers of living microbial forms have been ascertained to be present as contaminants in natural shea butter samples obtained from markets in West African countries, with the microflora differing from one market to another (Table 2). Microbes are ubiquitous and present 'at source', i.e. on freshly harvested shea fruits, shea nuts and all along the non-sterile, natural shea butter production and 
distribution systems, up to the point of sale to the final consumer. Microbial contamination in commercial natural shea butter from open markets is, therefore, not unexpected. The raw materials, aerial environment, personnel and packaging wares - all in contact at different stages with the product, are the attendant sources of, and contributors to its microbial contamination.

The traditional processing method for natural shea butter involves roasting and cooking operations at different stages (Olaoye, 1994), which are $\geqslant 100{ }^{\circ} \mathrm{C}$ heat treatments having attendant microbicidal effects. Subsequent nonsterile handling (milling, mixing, extraction, clarification, packaging and storage) of the product by the producers and/or retailers at the rustic markets presumably then re-contaminates it, resulting in its variable levels of microbial loads and contents at the time and points of sale. Those contamination levels would, therefore, depend absolutely on the various operators' hygienic standard.

Following its procurement from various market settings, natural shea butter is often put to domestic, culinary uses (cooking, frying or baking of recipes) or for cosmetics or formulations for topical application on human skin or scalp. This study was therefore, in part, aimed to reveal what levels of risk the users of "untreated" natural shea butter procured from markets may be routinely exposed to, when it is heavily contaminated as demonstrated in this study (Tables 2 and 3).

Oral consumption or skin application of microbes-contaminated shea butter may, respectively, cause gastrointestinal disease or skin infection for the user. Ingestion of pathogenic organisms that survived sub-lethal heat treatments and led to cases of food poisoning by Staphylococcus and Bacillus species have been reported (CDC, 1994; Argudín et al., 2010); as well as inadvertently applied contaminated topical cosmetic or therapeutic balm which caused skin infections due to Pseudomonas aeruginosa or Candida species (Balcht and Smith, 1994; Gow and Yadav, 2017), organisms present in natural shea butter (Table 3).
Hence, untreated natural shea butter could be very unsafe and unhygienic for ingestion or for direct topical use particularly in compromised skin health conditions, where its contaminating microbes could be opportunistic and have negative implications for its efficacy and intended use.

Our results indicate that despite its contamination levels (Tables 2 and 3), commercial natural shea butter as a human consumable (e.g. when intended or used as domestic cooking or frying oil) would become innocuous by subjecting it to $100{ }^{\circ} \mathrm{C}$ heat treatment for not less than 30 minutes prior to its consumption. The results of this study have, furthermore, demonstrated that hot filtration was a veritable technique for total sanitization of natural shea butter (Table 4), thereby endorsing the common laboratory or industrial practice.

\section{REFERENCES}

Abdul-Mumeen, I. 2013. Biochemical and microbiological analysis of shea nut cake: a waste product from shea butter processing, Master of Philosophy Thesis, Kwame Nkrumah University of Science and Technology, Kumasi, Ghana.

Addaquay, J. 2004. The shea butter value chain: refining in West Africa. Published by United States Agency for International Development; WATH Technical Report, No. 3.

Adebayo, A.S. and Akala, E.O. 2005. Kinetics model for the in vitro release of an hydrophilic drug (Amodiaquine) from fatbased suppositories. International Journal of Arts and Technology, 2:1-11.

Ademola, A.O., Oyesola, O.B. and Osewa, S.O. 2012. Assessment of shea butter processing among rural dwellers in Atisbo Local Government Area of Oyo State, Nigeria. European Journal of Business and Social Sciences, 1(6): 1-8.

Adesiji, G.B., Olarewaju, K.D., Olaleye, R.S. and Komolafe, S.E. 2015. Assessment of indigenous methods of processing shea butter among women in Ilorin East Local Government area of Kwara State, Nigeria. Journal of Agricultural Science, 60(2): 199-209. 
Alexander, R., Kralert, P.G. and Kagi, R.I. 1992. Kinetics and mechanism of the thermal decomposition of esters in sediments. Organic Geochemistry, 19(1-3): 133-140.

Argudín, M.A., Mendoza, M.C. and Rodicio, M.R. 2010. Food poisoning and Staphylococcus aureus enterotoxins. Toxins, 2: 17511773.

Balcht, A. and Smith, R. 1994. Pseudomonas aeruginosa: infections and treatment. Informa Health Care, Taylor \& Francis, UK, pp. 83-84.

British Pharmacopoeia (BP) 2009. British Pharmacopoeia Commission Office, London.

Bup, D.N., Kapseu, C., Mantos, L., Mabiala, B. and Mouloungui, Z. 2011. Influence of physical pretreatments of sheanuts (Vitellaria paradoxa Gaertn.) on butter quality. European Journal of Lipid Science and Technology, 113(9):1152-1160.

Centers for Disease Control and Prevention (CDC) 1994. Bacillus cereus food poisoning associated with fried rice at two child day care centers from "Morbidity and Mortality Weekly Report" 18 March 1994 /43(10), 177-178.

Couwan, S.T. and Steel, K.I. 1985. Manual for the identification of medical bacteria, Cambridge University Press, London, pp. 56-60, 217.

Djekota, C., Diouf, D., Sane, S., Mbaye, M.S. and Noba, K. 2014. Morphological characterization of shea tree (Vitellaria paradoxa sub sp. paradoxa) populations in the region of Mandoul in Chad. International Journal of Biodiversity and Conservation, 6(2): 184-193.

Goreja, W.G. 2004. Shea Butter: The nourishing properties of Africa's best-kept natural beauty, Amazing Herbs Press, New York, pp. 1-17.

Gow, N.A.R. and Yadav, B. 2017. Microbe profile: Candida albicans: a shape-changing, opportunistic pathogenic fungus of humans. Microbiology, 163: 1145-1147.

Honfo, F., Hell, K., Akissoe, N., Coulibaly, O., Fandohan, P. and Hounhouigan, J. 2011. Effect of storage conditions on microbiological and physicochemical quality of shea butter. Journal of Food Science and Technology, 48(3): 274-279.

Honfo, F.G., Hell, K., Akissoe, N., Linnemann, A. and Coulibaly, O. 2012. Microbiological and physicochemical characterization of shea butter sold on Benin markets. Journal of Stored Products and Postharvest Research, 3(3): 24-29.

Hilditch, T.P. and Williams, P.N. 1964. The chemical constitution of natural fats. Chapman and Hall, London, p. 439.

Megnanou, R. and Niamke, S. 2013. Effect of nut treatments on shea butter physicochemical criteria and wrapper hygienic quality influence on microbiological properties. Journal of Food Research, 2(5): 66-76.

Mohagir, A.M., Bup, N.D., Abi, C.F., Kamga, R. and Kapseu, R.C. 2015. Optimisation of decolourisation conditions of crude shea (Vitellaria paradoxa Gaertner F) butter: black type. Advances in Chemical Engineering Science, 5: 515-525.

Murray, P.R., Baron, E.J., Pfaller, M.A., Tenover, F.C. and Yolken, R.H. 1995. Manual of Clinical Microbiology. $6^{\text {th }}$ ed. ASM Press, Washington D.C., pp. 349-356.

Nahm, H.S. 2011. Quality characteristics of West African shea butter (Vitellaria paradoxa) and approaches to extend shelf-life, M.Sc. thesis, Graduate School New Brunswick Rutgers, The State University of New Jersey, New Jersey.

Nawar, W.W. 1984. Chemical Changes in lipids produced by thermal processing, Journal of ChemicalEducation, 61(4): 299-302.

Okullo, J.B.L., Hall, J.B. and Obua, J. 2004. Leafing, flowering and fruiting of Vitellaria paradoxa subsp. nilotica in savanna Parklands in Uganda. Agroforestry Systems, 60:77-91.

Olaniyan, A.M. and Oje, K. 2007. Quality characteristics of shea butter recovered from shea kernel through dry extraction process. Journal of Food Science and Technology, 44: 404-407.

Olaoye, J.O. 1994. Improving oil recovery process from shea butter seeds through clarification, M. Eng. Thesis, Department 
026 Oyedele et al.: Moderate Heat Treatments Enhance the Quality of Traded Natural Shea Butter

of Agricultural Engineering, University of Ilorin, Ilorin Nigeria.

Oyedele, A.O. 2016. Fluid emulsion base potential of shea butter. Journal of Pharmacy and Bioresources, 13(2): 103-113.

Samson, R.A. and van Reenan-Hoekstra, E.S.
1988. Introduction to food-borne fungi, $3^{\text {rd }}$ edn. CBS, Baarn. Delft, pp. 1-299.

Warra, A. A. 2011. Cosmetic potentials of African shea nut (Vitellaria paradoxa) butter. Current Research in Chemistry, 3(2): 8086. 